\title{
Aktivitas Herbisida Campuran Bahan Aktif Cyhalofop-Butyl dan Penoxsulam terhadap Beberapa Jenis Gulma Padi Sawah
}

\author{
Activity of Formulated-mix Herbicide with Active Ingredient of Cyhalofop-butyl and Penoxsulam \\ on Some Lowland Rice Weeds
}

Dwi Guntoro*, Trisnani Yuda Fitri

\begin{abstract}
Departemen Agronomi dan Hortikultura, Fakultas Pertanian, Institut Pertanian Bogor (Bogor Agricultural University), J1. Meranti, Kampus IPB Darmaga, Bogor 16680, Indonesia Telp.\&Faks.62-251-8629353 e-mail agronipb@indo.net.id
\end{abstract}

\begin{abstract}
Weed competition becomes a major problem in low land rice. Weeds can reduce rice production up to 60-70\%. Mixing herbicides is expected to obtain a broader spectrum of control of the weeds. Inappropriate mixing herbicides may cause antagonism effect which can reduce the effectiveness on the target weed. The objective of the research was to study the antagonism activity of two active ingredients herbicide mixture, cyhalofop-butyl and penoxulam. The treatment was consisted of three types of herbicide with five level of doses, i.e. a single herbicide cyhalofop-butyl $\left(0,375,750,1500\right.$, and $3000 \mathrm{~g}$ ai ha-1), penoxulam $\left(0,50,100,200\right.$, and $400 \mathrm{~g}$ ai ha $\left.\mathrm{a}^{-1}\right)$, and the mixture of cyhalofop- butyl $50 \mathrm{~g} \mathrm{~L}^{-1}+$ penoxulam $10 \mathrm{~g} \mathrm{~L}^{-1}(0,225,450,900$, and $1800 \mathrm{~g}$ ai hat $)$. The target weeds were Echinochloa cruss-galli and Monochoria vaginalis. Dry weight of biomass and percent of damage would further determine wheather the herbicide mixture were synergistic, antagonistic, or additive. Since cyhalofop-butyl and penoxulam had a different mode of action, analysis of the data used MSM (Multiplicative Survival Model) method to determine the LD50 of each herbicide treatment and mixture component. The result showed that an active ingredient mixture of cyhalofop-butyl $50 \mathrm{~g} \mathrm{~L}^{-1}+$ penoxulam $10 \mathrm{~g}$ $L^{-1}$ was not antagonist, with LD50-expectation values of $253.231 \mathrm{~g}$ ai ha $\mathrm{h}^{-1}$ and the LD50-treatment of $211.91 \mathrm{~g}$ ai $h a^{-1}$. The co-toxicity value was $1.19(>1)$.
\end{abstract}

Keywords: rice field weeds, cyhalofop-butyl, penoxulam, herbicide mixture, MSM (Multiplicative Survival Model), LD50

\section{ABSTRAK}

Kompetisi gulma menjadi masalah utama pada padi sawah. Gulma dapat mengurangi produksipadi hingga 60-70\%. Pencampuran herbisida diharapkan dapat memperluas spektrum pengendalian gulma. Pencampuran herbisida dapat menyebabkan efek antagonisme yang dapat mengurangi efektivitas pada gulma sasaran. Tujuan penelitian ini adalah untuk mempelajari adanya antagonisme pada pencampuran dua bahan aktif herbisida, yaitu cyhalofop-butyl dan penoxulam. Perlakuan terdiri dari tiga jenis herbisida dengan lima tingkat dosis, yaitu herbisida tunggal cyhalofop-butil $\left(0,375,750,1500\right.$, dan $3000 \mathrm{~g}$ ai ha $\left.\mathrm{a}^{-1}\right)$, penoxulam $(0,50,100,200$, dan $400 \mathrm{~g}$ ai $\left.\mathrm{ha}^{-1}\right)$, dan campuran herbisida dari cyhalofop-butil $50 \mathrm{~g} \mathrm{~L}^{-1}+$ penoxulam $10 \mathrm{~g} \mathrm{~L}^{-1}(0,225,450$, 900, dan $\left.1800 \mathrm{~g} \mathrm{ai} \mathrm{ha}^{-1}\right)$. Gulma yang menjadi sasaran adalah Echinochloa cruss-galli dan Monochoria vaginalis. Bobot kering biomassa dan persen dari kerusakan akan menentukan campuran herbisida yang sinergis, antagonis, atau aditif. Karena cyhalofop-butil dan penoxulam memiliki perbedaan cara kerja, analisis data yang digunakan adalah metode MSM (Multiplicative Survival Model) untuk menentukan LD50 tiap perlakuan herbisida dan komponen campuran. Hasil penelitian menunjukkan bahwa campuran bahan aktif dari cyhalofop-butil $50 \mathrm{~g}$ $\mathrm{L}^{-1}+$ penoxulam $10 \mathrm{~g} \mathrm{~L}^{-1}$ tidak antagonis, dengan nilai LD50-harapan $253.231 \mathrm{~g}_{\text {ai ha }}{ }^{-1}$ dan LD50-perlakuan $211.91 \mathrm{~g}$ ai ha $^{-1}$. Nilai co-toksisitas adalah 1.19 (> 1).

\footnotetext{
* Penulis untuk korespondensi. e-mail: dwiguntoro@yahoo.com
} 
Kata kunci: Campuranherbisida, cyhalofop-butil, gulmalapangan, LD50, padi, penoxulam, MSM(Multiplicative Survival Model)

\section{PENDAHULUAN}

Padi merupakan komoditas pangan utama bagi sebagian besar masyarakat Asia, terutama Indonesia. Produktivitas padi Indonesia pada tahun 2009 menunjukkan angka sebesar 49.99 ton ha ${ }^{-1}$ dengan produksi sebesar 64,398 juta ton. Peningkatan ini terjadi sejak tahun 2000 dimana produktivitas sebesar 44.1 ton $^{-1} \mathrm{~d}^{-1}$ dengan produksi 51.898 juta ton (Deptan, 2010). Jumlah penduduk dan kebutuhan beras yang meningkat, mendorong pemerintah untuk memperluas lahan persawahan guna mencukupi kebutuhan pangan penduduk.

Gulma merupakan masalah utama yang muncul sejak awal persiapan penanaman hingga menjelang panen padi di sawah. Penurunan produksi pangan khususnya padi akibat gulma masih sangat tinggi yakni berkisar antara $60-87 \%$. Data yang lebih rinci penurunan produksi padi secara nasional sebagai akibat gangguan gulma mencapai $15-42 \%$ untuk padi sawah dan padi gogo 47-87\% (Pitoyo, 2006). Oleh karena itu, diperlukan pengendalian yang dapat mengurangi persaingan gulma dengan padi sebagai tanaman budidaya utama.

Berbagai cara pengendalian gulma padi sawah dapat dilakukan dengan cara manual, mekanis, kultur teknis, maupun kimia. Saat ini, metode pengendalian yang paling banyak dilakukan adalah secara kimiawi dengan menggunakan herbisida (Barus, 2003). Pengendalian kimia dinilai lebih efektif untuk mengurangi populasi gulma dibandingkan dengan pengendalian lainnya. Penggunaan herbisida sebagai pengendali gulma mempunyai dampak positif yakni gulma dapat dikendalikan dalam waktu yang relatif singkat dan mencakup areal yang luas.

Pengendalian gulma selama ini terbatas pada penggunaan herbisida tunggal dengan satu jenis bahan aktifdan spesifik. Jenis herbisida selektif hanya mampu mengendalikan satu jenis gulma, dimana apabila salah satu gulma dikendalikan, maka gulma jenis lain yang lebih tahan akan menjadi dominan pada lahan, dan dapat menimbulkan masalah baru (Umiyati, 2005). Saat ini telah banyak dilaporkan adanya jenis-jenis gulma yang resisten terhadap herbisida sebagai akibat dari pengendalian gulma dengan menggunakan herbisida tunggal secara berulang-ulang. Sebanyak 352 biotipe gulma telah dilaporkan menjadi biotipe resisten (Weedscience, 2011). Penggunaan herbisida berbahan aktif sama secara berulang-ulang akan mematikan individu gulma yang rentan, tetapi meninggalkan individu yang resisten terhadap herbisida tersebut.

Perkembangan teknologi pencampuran herbisida dengan bahan aktif berbeda bertujuan untuk mendapatkan spektrum pengendalian yang lebih luas, serta diharapkan dapat memperlambat timbulnya gulma yang resisten terhadap herbisida, mengurangi biaya produksi, serta mengurangi residu herbisida. Salah satu hal yang harus dicermati dalam pencampuran herbisida adalah apakah campuran tersebut bersifat antagonistik atau tidak. Jika campuran herbisida tersebut bersifat antagonis, maka pengendalian gulma dengan herbisida campuran tersebut tidak akan efektif. Oleh karena itu, suatu campuran herbisida perlu diuji sifat aktivitasnya, dan ini ditentukan oleh jenis formulasi, cara kerja dan jenis-jenis gulma yang dikendalikan.

Pengujian sifat campuran herbisida dapat dilakukan melalui dua metode, yaitu ADM (Additive Dose Model) dan MSM (Multiplicative Survival Model). Metode ADM digunakan apabila komponen formulasi campuran herbisida memiliki mode of action (cara kerja) atau golongan yang sama, sedangkan metode MSM digunakan bila komponen formulasi memiliki mode of action atau golongan yang berbeda (Kristiawati, 2003).

Penoxsulam merupakan herbisida grup Triazolopyrimidines sulfonamide yang bekerja menghambat enzim acetolactate synthase (ALS). Bahan aktif ini memiliki spektrum luas, diabsorbsi oleh gulma terutama melalui daun, dan sebagian kecil melalui akar, dan ditranslokasikan. Rumus kimia dari penoksulam adalah $\mathrm{C}_{16} \mathrm{H}_{14} \mathrm{~F}_{5} \mathrm{~N}_{5} \mathrm{O}_{5} \mathrm{~S}$. Penoxsulam merupakan herbisida post emergence yang digunakan pada tanaman padi untuk mengendalikan gulma teki, gulma daun lebar, gulma air, dan rumputrumputan tertentu. Sedangkan bahan aktif cyhalofopbutyl merupakan herbisida post emergence untuk gulma golongan rumput-rumputan. Cyhalofop-butyl merupakan herbisida grup Aryloxyphenoxypropionate dengan rumus formula $\mathrm{C}_{16} \mathrm{H}_{12} \mathrm{FNO}_{4}$ yang bekerja menghambat ACCase (acetyl CoA carboxylase) (Weed Science, 2011).

Untuk menguji sifat campuran herbisida ini digunakan model MSM (Multiplicative Survival Model) sebagai dasaranalisis. Data persen kerusakan gulma dihitung dari bobot kering relatif terhadap control yang ditransformasikan ke dalam nilai probit (sebagai Y). Sedangkan dosis herbisida ditransformasi 
ke dalam bentuk logaritmik (sebagai X). Persamaan linier $(\mathrm{Y}=\mathrm{aX}+\mathrm{b})$ yang diperoleh digunakan untuk menhitung nilai LD50.

Kriteria sifat campuran dinilai dari perbandingan LD50 campuran percobaan dengan nilai LD50 campuran harapan berdasarkan model MSM. Jika LD50 campuran percobaan lebih kecil dari LD50 campuran harapan maka campuran tersebut bersifat sinergis, jika sebaliknya maka campuran tersebut bersifat antagonistik. Sedangkan bila keduanya menunjukkan persamaan maka campuran tersebut bersifat aditif.

Metode pencampuran herbisida tidak selalu menimbulkan beberapa reaksi yang besifat positif. Reaksi positif merupakan efek sinergis yang berarti pencampuran herbisida dapat meningkatkan efisiensi penggunaan herbisida dalam mengendalikan gulma sasaran. Gejala negatif ditunjukkan dengan reaksi antagonisme pada gulma sasaran yakni berkurangnya daya mematikan gulma. Oleh karena itu perlu dilakukan suatu pengujian pencampuran beberapa bahan aktif herbisida untuk mengetahui adanya aktivitas antagonisme herbisida.

Tujuan dari peneltian ini adalah untuk mempelajari adanya aktivitas antagonisme pada pencampuran dua bahan aktif herbisida cyhalofopbutyl dan penoxulam pada beberapa jenis gulma padi sawah.

\section{BAHAN DAN METODE}

Penelitian dilaksanakan di rumah kaca Kebun Percobaan IPB Cikabayan, Darmaga, Bogor. Penelitian dilaksanakan mulai bulan November 2010 hingga bulan Maret 2011.

Bahan yang digunakan pada penelitian ini meliputi herbisida bahan aktif cyhalofop-butyl (Clincher 100 EC), penoxulam (Clipper 25 OD), dan campuran herbisida cyhalofop- butyl $50 \mathrm{~g} \mathrm{~L}^{-1}+$ penoxulam $10 \mathrm{~g} \mathrm{~L}^{-1}$ (Topshot $60 \mathrm{OD}$ ), dua spesies gulma pada tanaman padi sawah yaitu Echinochloa cruss-galli dan Monochoria vaginalis. Media yang digunakan berupa tanah sawah latosol yang diperoleh dari lahan sawah sekitar kampus IPB Dramaga, Bogor.

Media dibuat menyerupai kondisi lingkungan tumbuh gulma air yang jenuh air. Media tanam berupa tanah sawah latosol dimasukkan ke dalam gelas cup sebanyak 120 buah yang telah dilubangi pada bagian dasar gelas untuk sirkulasi air. Pot selanjutnya diletakkan di dalam mangkuk sterofoam berisi air, sehingga media selalu dalam keadaan basah.

Bahan tanam diperoleh dengan cara mengumpulkan propagul gulma dari areal persawahan di sekitar kampus IPB Dramaga. Bahan tanam berupa bagian vegetatif atau anakan gulma. Anakan dari masing-masing spesies gulma diperoleh dengan mengambil tanaman yang sudah memiliki jumlah anakan yang cukup, kemudian dipindahtanamkan ke media pot untuk dipelihara sebelum diberikan perlakuan herbisida. Penyulaman dilakukan dengan mengganti tanaman baru yang memiliki ukuran atau umur seragam. Gulma dipelihara hingga mencapai tingkat recovery yang cukup untuk perlakuan herbisida selama kurang lebih 4 minggu.

Pemeliharaan berupa penyiraman dilakukan dengan mengisi air pada mangkuk sterofoam untuk menjaga kelembaban tanah dan ketersediaan air tanaman. Penyiraman dilakukan setiap hari selama penelitian berlangsung.

\section{Aplikasi Herbisida}

Perlakuan diberikan setelah gulma berumur 3 minggu setelah pindah tanam. Khusus untuk gulma $E$. crus-galli, aplikasi herbisida dilakukan setelah tanaman berumur 10 hari setelah tanam. Aplikasi herbisida dilakukan setelah bahan tanam dapat beradaptasi pada media pot. Herbisida disemprotkan dengan menggunakan knapsack sprayer dengan nozzle T-jet warna kuning dengan lebar semprot $0.5 \mathrm{~m}$. Kalibrasi larutan herbisida dengan volume semprot $500 \mathrm{~L} \mathrm{ha}^{-1}$ dengan waktu aplikasi 12 detik. Luas bidang semprot yang digunakan $1 \times 5 \mathrm{~m}^{2}$, dimana gulma diatur dalam luasan bidang semprot. Masing-masing perlakuan diulang sebanyak 4 kali.

Pengamatan dilakukan hingga kerusakan mencapai $90-95 \%$ untuk setiap individu gulma secara visual. Pemanenan gulma dilakukan pada 10-13 hari setelah aplikasi (HSA). Gulma dipisahkan antara bagian yang kering dan bagian yang masih segar. Masing-masing perlakuan ditempatkan di dalam kantong kertas dan diberi label, kemudian dioven

Tabel 1. Perlakuan berbagai jenis pestisida untuk setiap jenis gulma

\begin{tabular}{|c|c|c|c|}
\hline Perlakuan & $\begin{array}{c}\text { Cyhalofop-butyl } \\
\text { (g ai ha-1 ) }\end{array}$ & $\begin{array}{l}\text { Penoxulam } \\
\text { (g ai ha-1) }\end{array}$ & $\begin{array}{l}\text { campuran } \\
\text { (g ai ha-1) } \\
\end{array}$ \\
\hline $\mathrm{K}$ & 0 & 0 & 0 \\
\hline $\mathrm{R} 1$ & 375 & 50 & 225 \\
\hline R2 & 750 & 100 & 450 \\
\hline $\mathrm{R} 3$ & 1500 & 200 & 900 \\
\hline R4 & 3000 & 400 & 1800 \\
\hline
\end{tabular}


pada suhu $80^{\circ}$ Cselama 2 hari, kemudian ditimbang untuk memperoleh data bobot kering.

\section{Analisis Data}

Data bobot kering yang diperoleh selanjutnya dikonversi menjadi nilai persen keruskan. Persen keruskan dihitung dengan melihat tingkat kerusakan yang ditimbulkan oleh herbisida. Persen kerusakan dapat dihitung dengan menggunakan rumus:

$\begin{array}{ll}\text { \%kerusakan } & =\% \mathrm{KP}-\% \mathrm{KK} \\ \% \mathrm{KP} & =\{1-\mathrm{Bsp}\} \times 100 \% \text { Bsk } \\ \% \mathrm{KK} & =\{1-\mathrm{Bmk}\} \times 100 \% \text { Btk } \\ \% \text { ker. Camp. } & =\frac{\text { \%kerusakan } \mathrm{i}+\% \text { kerusakan } \mathrm{i}}{2}\end{array}$

Keterangan:

$\% \mathrm{KP}=$ persen kerusakan perlakuan

$\% \mathrm{KK}=$ persen kerusakan control

Bsp = bobot kering bagian gulma yang segar perlakuan $(\mathrm{g})$

Bsk $=$ bobot kering bagian gulma yang segar kontrol $(\mathrm{g})$

Bmk $=$ bobot kering bagian gulma yang mati control (g)

Btk $=$ bobot kering total gulma kontrol $(\mathrm{g})$

$i$ dan $j=$ spesies gulma tertentu

Persen kerusakan yang diperoleh selanjutnya dikonversi ke dalam nilai probit. Dari probit (y) dan $\log$ dosis ( $\mathrm{x}$ ) akan diperoleh persamaan regresi linier sederhana dengan menggunakan program SAS. Kemudian dari persamaan ini didapat nilai LD50 herbisida cyhalofop-butyl, penoxulam, dan campuran masing-masing terhadap gulma sasaran.

Nilai LD50 ini selanjutnya akan dianalisis dengan model MSM (Multiplicated Survival Model) untuk mengetahui apakah terdapat aktivitas antagonisme pada pencampuran herbisida (Gowing, 1960; Limpel, 1962). Model MSM digunakan untuk menguji campuran dua atau lebih herbisida yang memiliki cara kerja (mode of action) berbeda. Nilai harapan campuran dinyatakan sebagai $\mathrm{P}(\mathrm{A}+\mathrm{B})=\mathrm{P}(\mathrm{A})+\mathrm{P}(\mathrm{B})$ - $\mathrm{P}(\mathrm{A})(\mathrm{B})$, dimana $\mathrm{P}(\mathrm{A}+\mathrm{B})$ adalah nilai persen keruskan gulma dari herbisida campuran (Purwanti, 2003). Dalam penelitian ini, $\mathrm{P}(\mathrm{A}+\mathrm{B})$ adalah persen kemtian gulma dari herbisida campuran cyhalofopbutyl dan penoxulam, $\mathrm{P}(\mathrm{A})$ adalah persen keruskan gulma oleh herbisida cyhalofop-butyl, $\mathrm{P}(\mathrm{B})$ adalah persen keruskan gulma akibat herbisida penoxulam, sedangkan $\mathrm{P}(\mathrm{A})(\mathrm{B})$ adalah hasil kali persen keruskan $\mathrm{P}(\mathrm{A})$ dengan $\mathrm{P}(\mathrm{B})$. Nilai LD50 harapan dapat diperoleh dari persamaan $\mathrm{P}(\mathrm{A}+\mathrm{B})=50$, dimana $\mathrm{P}(\mathrm{A})$ dan $\mathrm{P}(\mathrm{B})$ diperoleh dari persamaan garis probit $\mathrm{Y}=\mathrm{a}+$ bX (Tjitrosoedirdjo, 2010).

\section{HASIL DAN PEMBAHASAN}

Pengendalian gulma dilakukan dengan tujuan mengurangi kompetisi yang disebabkan oleh gulma akibat pertumbuhan yang pesat. Dua gulma yang digunakanyaituEhinochloacruss-gallidanMonochoria vaginalis. E. cruss-galli merupakan tanaman tipe $\mathrm{C} 4$ yang memiliki tingkat efisiensi fotosintesis yang rendah dan boros dalam penggunaan air. Hal inimenyebabkan gulma lebih banyak menyerap dan menggunakan nutrisi dari tanah dibanding tanaman padi, sehingga menimbulkan kompetisi (Nyarko and De Datta, 1991). M. vaginalis merupakan tanaman tipe C3 seperti halnya padi sawah. Gulma ini menjadi invasive karena memiliki kecepatan tumbuh yang tinggi melalui perbanyakan vegetatif (Caton et al., 2010).

Aplikasi herbisida memperlihatkan pengaruh pada gulma sasaran yang diujikan yaitu Echinochloa cruss-galli dan Monochoria vaginalis. Ketiga jenis bahan aktif herbisida yang digunakan memiliki sifat sistemik, sehingga pengaruh herbisida belum bisa terlihat pada 1 HSA (hari setelah aplikasi). Gulma E. cruss-galli mulai mengering pada bagian pangkal batang dan pada 5 HSA, sedangkan pada M. vaginalis, daun terlihat mengalami kelayuan yang dimulai dari bagian daun tua pada 7 HSA. Proses kematian dapat digambarkan melalui tabel persen kerusakan masing-masing gulma oleh perlakuan herbisida pada Tabel 2 dan 3.

\section{Analisis Kerusakan Gulma}

Kerusakan gulma dihitung berdasarkan analisis bobot kering bagian gulma yang rusak akibat perlakuan herbisida (Tabel 4). Berdasarkan pengamatan bobot

Tabel 2. Data kerusakan gulma E. crus-galli (\%) setelah aplikasi herbisida campuran $(\mathrm{A}+\mathrm{B})$, cyhalofop- butyl (A), dan penoxulam (B)

\begin{tabular}{lccc}
\hline Perlakuan & $\begin{array}{c}\text { Cyhalofop-butyl } \\
\left(\mathrm{g} \mathrm{ai} \mathrm{ha}^{-1}\right)\end{array}$ & $\begin{array}{c}\text { Penoxulam } \\
\left(\mathrm{g} \mathrm{ai} \mathrm{ha}^{-1}\right)\end{array}$ & $\begin{array}{c}\text { campuran } \\
\left(\mathrm{g} \mathrm{ai} \mathrm{ha}^{-1}\right)\end{array}$ \\
\hline K & 0 & 0 & 0 \\
R1 & 375 & 50 & 225 \\
R2 & 750 & 100 & 450 \\
R3 & 1500 & 200 & 900 \\
R4 & 3000 & 400 & 1800 \\
\hline
\end{tabular}


Tabel 3. Data kerusakan gulma M. vaginalis (\%) setelah aplikasi herbisida campuran (A+B), cyhalofop- butyl (A), dan penoxulam (B)

\begin{tabular}{lllcccc}
\hline Bahan Aktif & Perlakuan & $\begin{array}{l}\text { Dosis } \\
\text { g ai ha-1 }\end{array}$ & U1 & U2 & U3 & Rata-rata \\
\cline { 3 - 5 } & & 0 & - & - & - & - \\
\hline A+B & K & 225 & 43.04 & 39.60 & 36.05 & 34.40 \\
& R1 & 450 & 60.96 & 77.80 & 80.61 & 81.11 \\
& R2 & 900 & 84.50 & 88.55 & 87.42 & 87.04 \\
& R3 & 92.50 & 91.78 & 98.12 & 96.25 \\
& R4 & 1800 & & & & \\
A & K & 0 & 18.99 & 27.37 & 19.24 & 21.87 \\
& R1 & 375 & 30.00 & 49.63 & 59.28 & 46.30 \\
& R2 & 750 & 73.21 & 93.21 & 94.49 & 86.97 \\
& R3 & 1500 & 91.85 & 93.21 & 96.20 & 93.75 \\
B & 3000 & & & & \\
& R4 & 0 & 32.52 & 16.99 & 19.84 & 23.12 \\
& K & 50 & 52.36 & 33.73 & 24.33 & 36.81 \\
& R1 & 100 & 62.16 & 52.46 & 66.82 & 60.48 \\
& R2 & 200 & 71.56 & 54.30 & 71.97 & 65.94 \\
\hline
\end{tabular}

kering gulma menunjukkan hasil yang tidak seragam, meskipun pada awal persiapan sebelum aplikasi herbisida gulma memiliki keseragaman tinggi pada setiap blok/ ulangan. Pengamatan menunjukkan bahwa bobot kering bagian segar gulma yang diberikan perlakuan herbisida lebih kecil dari bobot kering tanpa perlakuan herbisida (dosis $0 \mathrm{~g}$ ai ha ${ }^{-1}$ ).

Persen kerusakan gulma merupakan rata-rata penjumlahanpada setiap ulangan dari gabungan gulma Monochoria vaginalis dan Echinochloa cruss-galli (Tabel 5). Data persen kerusakan berupa persen kematian gabungan tersebut nantinya diperlukan untuk mengetahui tipe campuran herbisida cyhalofop- butyl dan penoxulam.

Nilai persen kematian kontrol tidak digunakan (= nol) untuk menunjukkan bahwa tidak terdapat pengaruh herbisida.

\section{Nilai Probit}

Perlakuan dosis dan persen kerusakan gabungan menggambarkan seberapa besar herbisida dapat menimbulkan kerusakan pada gulma sasaran apabila berada pada kondisi sebenarnya di lapangan. Hubungan antara dosis dan persen kerusakan dapat diketahui melalui transformasi ke dalam nilai probit. Transformasi dilakukan dengan bantuan tabel probit, begitu juga dosis herbisida (dalam $\mathrm{g} \mathrm{ha}^{-1}$ ) ditransformasi dalam bentuk logaritmik (Tabel 6). Probit merupakan fungsi kerusakan gulma berupa persamaan regresi linier sederhana, yaitu $\mathrm{Y}=\mathrm{a}+$ $\mathrm{bX}$, dimana $\mathrm{Y}$ adalah nilai probit dari persen kerusakan gulma gabungan, dan $\mathrm{X}$ adalah log dosis perlakuan herbisida.

\section{$L D 50$}

Persamaan regresi yang didapat selanjutnya digunakan untuk menentukan LD50 dari masingmasing perlakuan jenis herbisida. LD50 menunjukkan dosis yang menyebabkan kerusakan gulma 50\%. Perhitungan LD50 diperlukan untuk mengetahui dosis perlakuan dan angka harapan pada kerusakan 50\%. Kerusakan $50 \%$ yang diinginkan merupakan nilai $\mathrm{Y}$ dari persamaan regresi, yang ditransformaikan ke dalam nilai probit, yaitu 5. Nilai $\mathrm{X}$ adalah log dosis dari masing-masing perlakuan, sehingga untuk menentukan LD50 log dosis harus dikembalikan ke dalam antilog (X).

Analisis Campuran Herbisida

Persamaan regresi yang didapat digunakan untuk menentukan nilai LD50 dari perlakuan herbisida yang diaplikasikan pada dua jenis gulma $M$. vaginalis dan E. cruss-galli. Tabel 7 menerangkan hasil analisis regresi linier sederhana dan nilai LD50 dari masingmasing perlakuan herbisida,

Nilai LD50 dari perlakuan herbisida campuran cyhalofop- butyl dan penoxulam sebesar $211.91 \mathrm{~g}$ ai $\mathrm{ha}^{-1}$. Angka tersebut selanjutnya digunakan untuk 
Tabel 4. Data bobot kering bagian segar gulma E.crus-galli dan M. vaginalis setelah aplikasi herbisida campuran $\mathrm{A}+\mathrm{B}$, cyhalofop-butyl (A), dan penoxulam (B)

\begin{tabular}{|c|c|c|c|c|c|c|c|}
\hline \multirow[t]{2}{*}{ Gulma } & \multirow[t]{2}{*}{ Bahan aktif } & \multirow[t]{2}{*}{ Perl. } & \multirow{2}{*}{$\begin{array}{l}\text { Dosis } \\
\text { g ai ha }{ }^{-1}\end{array}$} & \multicolumn{3}{|c|}{ Bobot Kering Bagian Segar } & \multirow[t]{2}{*}{ Rata-rata } \\
\hline & & & & $\mathrm{U} 1$ & $\mathrm{U} 2$ & U3 & \\
\hline \multirow[t]{15}{*}{ E. crussgalli } & $\mathrm{A}+\mathrm{B}$ & $\mathrm{K}$ & 0 & 0.165 & 0.114 & 0.110 & 0.130 \\
\hline & & $\mathrm{R} 1$ & 225 & 0.094 & 0.069 & 0.069 & 0.077 \\
\hline & & $\mathrm{R} 2$ & 450 & 0.064 & 0.025 & 0.020 & 0.036 \\
\hline & & $\mathrm{R} 3$ & 900 & 0.025 & 0.013 & 0.012 & 0.017 \\
\hline & & $\mathrm{R} 4$ & 1800 & 0.012 & 0.009 & 0.000 & 0.007 \\
\hline & A & $\mathrm{K}$ & 0 & 0.172 & 0.157 & 0.102 & 0.144 \\
\hline & & $\mathrm{R} 1$ & 375 & 0.172 & 0.112 & 0.082 & 0.122 \\
\hline & & $\mathrm{R} 2$ & 750 & 0.138 & 0.077 & 0.041 & 0.086 \\
\hline & & $\mathrm{R} 3$ & 1500 & 0.119 & 0.009 & 0.005 & 0.044 \\
\hline & & $\mathrm{R} 4$ & 3000 & 0.045 & 0.009 & 0.003 & 0.019 \\
\hline & B & $\mathrm{K}$ & 0 & 0.201 & 0.125 & 0.089 & 0.138 \\
\hline & & $\mathrm{R} 1$ & 50 & 0.135 & 0.102 & 0.071 & 0.103 \\
\hline & & $\mathrm{R} 2$ & 100 & 0.095 & 0.081 & 0.067 & 0.081 \\
\hline & & $\mathrm{R} 3$ & 200 & 0.075 & 0.058 & 0.029 & 0.054 \\
\hline & & $\mathrm{R} 4$ & 400 & 0.056 & 0.055 & 0.025 & 0.045 \\
\hline \multirow[t]{15}{*}{ M. vaginalis } & $\mathrm{A}+\mathrm{B}$ & K & 0 & 0.783 & 0.820 & 0.782 & 0.795 \\
\hline & & $\mathrm{R} 1$ & 225 & 0.124 & 0.423 & 0.087 & 0.211 \\
\hline & & $\mathrm{R} 2$ & 450 & 0.026 & 0.07 & 0.089 & 0.062 \\
\hline & & $\mathrm{R} 3$ & 900 & 0.017 & 0.053 & 0.037 & 0.036 \\
\hline & & $\mathrm{R} 4$ & 1800 & 0.009 & 0.036 & 0.018 & 0.021 \\
\hline & A & K & 0 & 0.783 & 0.82 & 0.782 & 0.795 \\
\hline & & $\mathrm{R} 1$ & 375 & 0.294 & 0.176 & 0.283 & 0.251 \\
\hline & & $\mathrm{R} 2$ & 750 & 0.157 & 0.135 & 0.137 & 0.143 \\
\hline & & $\mathrm{R} 3$ & 1500 & 0.078 & 0.114 & 0.095 & 0.096 \\
\hline & & $\mathrm{R} 4$ & 3000 & 0.039 & 0.094 & 0.047 & 0.06 \\
\hline & B & $\mathrm{K}$ & 0 & 0.883 & 0.081 & 0.782 & 0.582 \\
\hline & & R1 & 50 & 0.123 & 0.189 & 0.098 & 0.137 \\
\hline & & $\mathrm{R} 2$ & 100 & 0.123 & 0.104 & 0.038 & 0.088 \\
\hline & & $\mathrm{R} 3$ & 200 & 0.162 & 0.052 & 0.02 & 0.078 \\
\hline & & $\mathrm{R} 4$ & 400 & 0.081 & 0.000 & 0.001 & 0.027 \\
\hline
\end{tabular}

menganalisis sifat campuran kedua jenis herbisida dengan menggunakan metode MSM (Multiplicative Survival Models).

\section{Model MSM (Multipliated Survival Model)}

Sifat campuran herbisida ditentukan dengan membandingkan nilai LD50 Harapan dengan nilai LD50 Perlakuan.

Diketahui:

Nilai LD50 Perlakuan campuran herbisida A (cyhalofop-butyl) + B (penoxulam) sebesar $211.91 \mathrm{~g}$ ai ha $^{-1}$. Perbandingan komponen campuran $\mathrm{A}: \mathrm{B}=5$ : 1. Nilai LD50 Perlakuan masing-masing komponen :
- cyhalofop-butyl $(\mathrm{X} 1)=472.72 \mathrm{~g}$ ai ha ${ }^{-1}$

- penoxulam $(\mathrm{X} 2)=105.84 \mathrm{~g}$ ai ha $^{-1}$

LD50 Harapan dihitung berdasarkan perubahan nilai komponen campuran diatas (X1 dan X2) dalam proporsi perbandingan tetap $(\mathrm{A}: \mathrm{B}=5: 1)$ hingga perubahan nilai dosis tersebut dapat menyebabkan kerusakan gulma sebesar $50 \%$. Nilai dosis komponen campuran dimasukkan ke dalam persamaan regresi dari masingmasing herbisida tunggal dalam bentuk logaritmik, sehingga dengan mengacu pada tabel probit dapat dihitung persen kerusakan gulma yang disebabkan baik oleh cyhalofop-butyl dan penoxulam.

Dengan merubah-rubah nilai X1 dan X2 tersebut, maka diperoleh dosis dari masing-masing 
Tabel 5. Data kerusakan gabungan gulma E. crus-galli dan M. vaginalis (\%) setelah aplikasi herbisida campuran $(\mathrm{A}+\mathrm{B})$, _ cyhalofop- butyl $(\mathrm{A})$, dan penoxulam (B)

\begin{tabular}{|c|c|c|c|c|c|c|}
\hline \multirow[t]{2}{*}{ Bahan aktif } & \multirow[t]{2}{*}{ Perlakuan } & \multirow{2}{*}{$\begin{array}{l}\text { Dosis } \\
\text { g ai ha }^{-1}\end{array}$} & \multicolumn{3}{|c|}{$\%$ Kematian } & \multirow[t]{2}{*}{ Rata-rata } \\
\hline & & & U1 & U2 & U3 & \\
\hline \multirow[t]{5}{*}{$\mathrm{A}+\mathrm{B}$} & $\mathrm{K}$ & 0 & - & - & - & - \\
\hline & $\mathrm{R} 1$ & 225 & 44.50 & 61.43 & 35.24 & 47.06 \\
\hline & $\mathrm{R} 2$ & 450 & 69.51 & 84.17 & 84.62 & 79.43 \\
\hline & $\mathrm{R} 3$ & 900 & 84.40 & 90.71 & 91.37 & 88.83 \\
\hline & R4 & 1800 & 93.97 & 94.66 & 98.48 & 95.71 \\
\hline \multirow[t]{5}{*}{ A } & $\mathrm{K}$ & 0 & - & - & - & - \\
\hline & $\mathrm{R} 1$ & 375 & 40.69 & 45.57 & 40.38 & 42.21 \\
\hline & $\mathrm{R} 2$ & 750 & 56.26 & 66.19 & 64.22 & 62.22 \\
\hline & $\mathrm{R} 3$ & 1500 & 79.74 & 90.54 & 84.57 & 84.95 \\
\hline & $\mathrm{R} 4$ & 3000 & 92.49 & 93.57 & 88.06 & 91.38 \\
\hline \multirow[t]{5}{*}{ B } & $\mathrm{K}$ & 0 & - & - & - & - \\
\hline & $\mathrm{R} 1$ & 50 & 35.92 & 34.83 & 32.05 & 34.27 \\
\hline & $\mathrm{R} 2$ & 100 & 51.46 & 45.66 & 48.18 & 48.43 \\
\hline & $\mathrm{R} 3$ & 200 & 62.38 & 65.93 & 77.52 & 68.61 \\
\hline & R4 & 400 & 71.40 & 69.16 & 80.63 & 73.73 \\
\hline
\end{tabular}

Tabel 6. Transformasi probit nilai rata-rata persen kerusakan dari 2 jenis gulma yang uji

\begin{tabular}{lccccc}
\hline Bahan Aktif & Perlakuan & Log Dosis & \multicolumn{3}{c}{ Nilai Probit } \\
\cline { 3 - 5 } & & & U1 & U2 & U3 \\
\hline A+B & R1 & 2.352 & 4.862 & 5.290 & 4.620 \\
& R2 & 2.653 & 5.510 & 6.003 & 6.019 \\
R3 & 2.954 & 6.011 & 6.323 & 6.366 \\
A & 3.255 & 6.555 & 6.616 & 7.171 \\
& R1 & 2.574 & 4.765 & 4.890 & 4.757 \\
& R2 & 2.875 & 5.159 & 5.418 & 5.364 \\
B & R3 & 3.176 & 5.831 & 6.311 & 6.019 \\
& R4 & 3.477 & 6.440 & 6.522 & 6.18 \\
& R1 & 1.699 & 4.639 & 4.609 & 4.535 \\
& R2 & 2.000 & 5.038 & 4.692 & 5.955 \\
& R3 & 2.301 & 5.316 & 5.410 & 5.755 \\
\end{tabular}

herbisida komponen campuran adalah sebesar:

- cyhalofop-butyl (X1) $=211.02 \mathrm{~g}$ ai ha $^{-1}$

- Penoxulam (X2) $=42.21 \mathrm{~g}$ ai ha-1 $^{-1}$

Dengan dosis tersebut, maka kerusakan gulma

oleh masingmasing komponen campuran (nilai probit) adalah sebesar:

- cyhalofop-butyl (Y1) $=4.3635$

- Penoxulam (Y2) = 4.5032

Jika dikonversi dalam bentuk anti-probit, maka kerusakan gulma oleh masing-masing komponen herbisida tersebut adalah

sebesar :

- cyhalofop-butyl (Y1) $=26.2 \%(P A)$

- Penoxulam (Y2) $=31.0 \%(P B)$

Tingkat kerusakan gulma 50\% (harapan) diketahui berdasarkan persamaan probit:

$P(A B)=P A+P B-P A P B($ nilai $P A P B=8.1220)$

Persamaan Probit: $P(A B)=26.2+31.0-8.1220$

Jadi : 
Tabel 7. Persamaan regresi dan analisis ragam: $\mathrm{Y}=$ nilai probit dari rata-rata persen kerusakan 2 jenis gulma, $\mathrm{X}=\log$ dosis

\begin{tabular}{|c|c|c|c|c|}
\hline Formulasi Hibridisasi & Persamaan Garis & $\mathrm{P}$ & $\begin{array}{c}\text { Nilai } \\
\text { r2 } \\
(\%)\end{array}$ & $\begin{array}{c}\text { LD50 } \\
\text { perlakuan } \\
\text { (gr ai/ha) }\end{array}$ \\
\hline Campuran & $Y=0.395+1.979 X$ & $<0.0001$ & 85.9 & 211.91 \\
\hline \multicolumn{5}{|l|}{$\mathrm{A}+\mathrm{B}$} \\
\hline A & $\mathrm{Y}=0.139+1.817 \mathrm{X}$ & $<0.0001$ & 93.4 & 472.72 \\
\hline \multicolumn{5}{|l|}{ Cyhalofop-butyl } \\
\hline B & $\mathrm{Y}=2.481+1.244 \mathrm{X}$ & $<0.0001$ & 85.6 & 105.84 \\
\hline
\end{tabular}

LD50 Harapan $=221.02+42.21$

$$
=253.23 \mathrm{~g} \text { ai ha-1 }^{-1}
$$

LD50 Percobaan $=211.91 \mathrm{~g}$ ai ha-

Ko-toksisitas:

LD50 Harapan/LD50 Percobaan $=253.23 / 211.91$

$$
=1.19
$$

Berdasarkan hasil perhitungan dengan model MSM di atas, maka nilai LD50 Percobaan lebih kecil daripada LD50 Harapan, nilai ko-toksisitas $=1.19$, atau lebih dari satu $(>1)$.

\section{Interaksi Herbisida}

Berdasarkan análisis model MSM diketahui bahwa nilai kotoksisitas herbisida lebih dari satu $(>1)$, yang berarti campuran herbisida cyhalofop-butyl dan penoxulam tidak bersifat antagonis pada dua gulma Monochoria vaginalis dan Echinochloa crussgalli. Nilai harapan menunjukkan bahwa pada penggunaan cyhalofop-butyl dosis sebesar $221.02 \mathrm{~g}$ ai ha-1 dan penoxulam dosis $42.21 \mathrm{~g}$ ai ha-1 herbisida telah mampu menyebabkan kematian 50\% gulma.

Cyhalofop-butyl dan penoxulam merupakan herbisida yang memiliki perbedaan golongan kimia yaitu Arylopenoxypropionate yang menghambat kerja enzim Acetil CoEnzim A Carboxylase dan Triazolepyrimidynes solfonamide yang menghambat pembentukkan anzim acetolactate syntase. Damalas (2004) menyebutkan bahwa dengan adanya perbedaan golongan/grup bahan kimia, mode of action, dan pengaruh terhadap jalur, metabolisme, campuran herbisida dapat saling berinteraksi dalam menghambat kerja enzin atau proses fisiologis gulma.

\section{KESIMPULAN}

Pencampuran herbisida bahan aktif cyhalofop butyl $50 \mathrm{~g}$ L-1 dan penoxulam $10 \mathrm{~g} \mathrm{~L}^{-1}$ memiliki nilai LD50 Harapan sebesar $402.629 \mathrm{~g}$ ai $\mathrm{ha}^{-1}$ dan nilai LD50 Perlakuan sebesar $211.91 \mathrm{~g}$ ai ha ${ }^{-1}$ dengan ko- toksisitas sebesar 1.19. Nilai LD50 Harapan lebih kecil dibandingkan dengan nilai LD50 Perlakuan (kotoksisitas $>1$ ), sehingga campuran herbisida tidak bersifat antagonis.

\section{DAFTAR PUSTAKA}

Barus, E. 2003. Pengendalian Gulma di Perebunan. Kanisius. Yogyakarta.

Caton, B.P., M. Mortimer, J.E. Hill, E. Johnson. 2010. A Practical Field Guide to Weeds of Rice in Asia. $2^{\text {nd }}$ Edition. International Rice Research Institute. Los Banos.

Damalas, C.A. 2004. Herbicide tank mixtures: common interactions. J. Agri. Biol. 6(1) : 209212.

Departemen Pertanian Republik Indonesia. 2010. Basis Data Pertanian. http://www.deptan.go.id. [Maret 2011].

Gowing, D.P. 1960. Comment on test of herbicide mixture. Weeds 8: 379-391.

Kristiawati, I. 2003. Uji tipe campuran herbisida fluroksipir dan glifosat (Topstar 50/300 EW) menggunakan gulma Paspalum conjugatum Berg. dan Mikania micrantha (L.) Kunth. Skripsi. Jurusan Biologi, Fakultas Matemaika dan Ilmu Pengetahuan Alam, Institut Pertanian Bogor. Bogor. 26 hal.

Limpel, L.E., P.H. Schultdz, D. Lamont. 1962. Weed ontrol by dimetyl tetrachloroterephthalate alone and in certain combination. Proc. Northeast, Weed Sci. Soc. 16: 48-53.

Nyarko, K.A., S.K. De Datta. 1991. A for Weed Control in Rice in Asia. International Rice Research Institute. Los Banos.

Pitoyo, J. 2006. Mesin penyiang gulma padi sawah 
bermotor. Sinar Tani.7: 5-11.

Purwanti. 2003. Uji tipe campuran herbisida Glifosat dan 2,4-D (Bimastar 240/120 AS) dengan memakai gulma Brachiaria paspaloides dan Bidens pilosa. Skripsi. Departemen Biologi, Fakultas Matemaika dan Ilmu Pengetahuan Alam, Institut Pertanian Bogor. Bogor.

Tjitrosoedirdjo, S. 2003. Uji sinergisme campuran dua bahan aktif herbisida dengan metoda probit. Jurnal Gulma dan Tumbuhan Invasif Tropika. 1(1): 16-28.
Umiyati, U. 2005. Sinergisme campuran herbisida klomazon dan metribuzin terhadap gulma. Jurnal Agrijati. 1(1): 216-219.

Weedscience. 2011. Herbicide Resistant Weed Summary Table. http:/wwww.weedscience. org. [Januari 2011]. 